\title{
Age related histomorphochemical changes in ovaries of Punjab white quail
}

\begin{abstract}
The present study was undertaken to elucidate histomorphological and histochemical studies on ovaries of Punjab white quail. The birds were divided into four age groups 8 weeks, 16weeks, 24 weeks and 30 weeks. The study revealed that entire ovary was covered by single layer of squamous to cuboidal epithelium depended on the presence or absence of follicles. The cortex was separated from medulla by a thin layer of connective tissue called tunica albuginea at 8 weeks of age. The tunica albuginea was composed of abundance of collagen fibers with few reticular and elastic fibers. This layer started regress at 16 weeks and was completely diminished at 24 weeks and 30 weeks of age. The medulla was comprised of loose connective tissue and large number of blood vessels, lymph vessels and lacunars channels. With advancing age, these lacunars channels increased in number. Smooth muscle fibers along with nerve fibers were also seen. Micrometrical data showed that the mean height of the epithelium increased with the age but was maximum at 24 weeks of age whereas thickness of the cortex and medulla was maximum at 16 and 8 weeks of age. Histochemical studies revealed that PAS reaction was strong in the surface epithelium, moderate in the cortex and medulla. Acid mucoploysaccharides were strong in the surface epithelium, moderate in cortex and theca layers, weak in medulla. Surface epithelium showed strong to intense reaction for basic proteins. Sudanophillic lipids were weak in the epithelium, cortex and medulla.
\end{abstract}

Keywords: histomorphology, cortex, medulla, ovary, Punjab white quail
Volume 3 Issue I - 2018

\section{Meenu Bala,Anuradha Gupta, Neelam Bansal, Varinder Uppal}

Guru Angad Dev Veterinary and Animal Sciences University, India

Correspondence: Anuradha Gupta, Department of Veterinary Anatomy, Guru Angad Dev Veterinary and Animal Sciences University, Ludhiana, Punjab, India, Email anugadvasu@gmail.com

Received: November 22, 2017 | Published: January 12, 2018

\section{Introduction}

In India, quail was introduced two decades ago and has partially replaced the domestic fowl both in research and open market for human consumption. The quail originally domesticated around $11^{\text {th }}$ century as a pet song bird, is now highly valued. ${ }^{1,2}$ Quail reproduces throughout the year on contrary to seasonally breeding birds. It attains the maturity at 28 days and first decline of fertility has been recorded at 12 months and last egg laid or $90 \%$ fertility loss at $17-24$ months of age. ${ }^{3}$ The advantages of quail farming includes minimum floor space, low investment, comparatively sturdy birds, early market age and sexuality, high rate of egg production and less feed requirement. ${ }^{4}$ Besides, Quail meat and egg are tastier than chicken and has less fat contents. It has been shown to promote body and brain development in children and nursing mothers. ${ }^{5}$ In quail farming, the reproductive and immune status of birds is of prime importance to obtain good production. ${ }^{6}$

Quail females begin to lay eggs at the age of 45 days and the peak of egg production is attained at 5 month of age. ${ }^{7}$ The short life cycle, the high fecundity and adaptability to life in cages, the low maintenance cost, and the easy ways to raise and handle it, make the quail an ideal model for research. In comparative studies between chicken and Japanese quail, the latter gives an annual egg mass production twenty times higher than the female adult body weight, while it is only ten times in hen. ${ }^{8}$ The literature is available on the histomorphology and histochemistry on ovaries of duck, ${ }^{9,10}$ Japanese quail, ${ }^{11}$ Spotted tinamou's, ${ }^{12}$ Chicken, ${ }^{13}$ Punjab white quail ${ }^{14}$ and domestic hen ${ }^{15}$ but information on age related changes in histomorphochemical studies of ovary in different ages of Punjab White Quail is very scanty. Keeping in view the scarcity of literature the present study was planned with the following objectives: i. To provide information on histomorphology of ovaries of Punjab white quail in various age groups.

ii. To establish histochemical norms of ovaries of Punjab white quail at different ages.

\section{Materials and methods}

The present study was conducted on ovaries of 24 Punjab white quails. The ovaries of different age were collected from poultry farm, GADVASU, Ludhiana. Before collections of samples, the ovaries were thoroughly examined for any pathological lesions. The female birds of various ages were selected and grouped as 8 weeks, 16 weeks, 24 weeks and 30 weeks. The tissue samples were collected after slaughter of the birds. The particulars of birds have been described in Table1. The ovaries were fixed in $10 \%$ neutral buffered formalin (NBF) immediately after collection. Once the fixation was achieved, the ovaries were processed for paraffin block preparation by acetonebenzene schedule. ${ }^{16}$ The blocks were prepared and sections of $5 \mu \mathrm{m}$ thickness were cut with rotary microtome and obtained on clean glass slides. The paraffin sections were stained with different stains to study the histomorphological (Table 2) and histochemical details (Table 3). Micrometrical observations were recorded on hematoxylin and eosin stained sections with help of image analysis system loaded in digital microscope micrometer. The epithelial height, thickness of cortex and medulla were recorded in ovaries of all age groups (Table 1-3).

\section{Statistical analysis}

Arithmetic mean, Standard error and correlation for morphometric measurements were computed and statistically analyzed for their significance. ${ }^{17}$ 
Table I Details of ovaries of Punjab white quail used in study

\begin{tabular}{|c|c|c|c|}
\hline Sr. no. & Group & Bird no. & Source \\
\hline I & Group I (8 Weeks) & Al & $\begin{array}{l}\text { GADVASU, } \\
\text { Poultry Farm }\end{array}$ \\
\hline 2 & -do- & $\mathrm{A} 2$ & -do- \\
\hline 3 & -do- & $\mathrm{A} 3$ & -do- \\
\hline 4 & -do- & A4 & -do- \\
\hline 5 & -do- & A5 & -do- \\
\hline 6 & -do- & A6 & -do- \\
\hline 7 & Group II (I6 Weeks) & $\mathrm{BI}$ & -do- \\
\hline 8 & -do- & B2 & -do- \\
\hline 9 & -do- & B3 & -do- \\
\hline 10 & -do- & B4 & -do- \\
\hline II & -do- & B5 & -do- \\
\hline 12 & -do- & B6 & -do- \\
\hline 13 & Group III (24 Weeks) & $\mathrm{Cl}$ & -do- \\
\hline 14 & -do- & $\mathrm{C} 2$ & -do- \\
\hline 15 & -do- & $\mathrm{C} 3$ & -do- \\
\hline 16 & -do- & $\mathrm{C} 4$ & -do- \\
\hline 17 & -do- & $\mathrm{C} 5$ & -do- \\
\hline 18 & -do- & $\mathrm{C} 6$ & -do- \\
\hline 19 & Group IV (30 Weeks) & DI & -do- \\
\hline 20 & -do- & D2 & -do- \\
\hline 21 & -do- & D3 & -do- \\
\hline 22 & -do- & D4 & -do- \\
\hline 23 & -do- & D5 & -do- \\
\hline 24 & -do- & D6 & -do- \\
\hline
\end{tabular}

Table 2 Histomorphological techniques used on paraffin sections of ovaries of Punjab white quail

\begin{tabular}{llll}
\hline Sr. no. & Purpose & Method & Source \\
\hline I & Routine Morphology & Hematoxylin And Eosin & Luna $^{16}$ \\
2 & Collagen Fibres & Masson's Trichrome & $\begin{array}{l}\text { Luna }^{16} \\
\text { Sheehan \& }\end{array}$ \\
3 & Elastic Fibres & Verhoeff's & $\begin{array}{l}\text { Hrapchak } \\
\text { He }\end{array}$ \\
4 & Reticular Fibres & Gridley's & $\begin{array}{l}\text { Sheehan \& } \\
\text { Hrapchak }\end{array}$ \\
5 & Neuronal Elements & Holme's & Luna $^{16}$ \\
\hline
\end{tabular}

Table 3 Histochemical techniques used on paraffin sections of ovaries of Punjab white quail

\begin{tabular}{llll}
\hline Sr. no. & Purpose & Method & Source \\
\hline 1 & $\begin{array}{l}\text { Neutral } \\
\text { Mucopolysaccharides }\end{array}$ & Periodic Acid Schiff & $\begin{array}{l}\text { Sheehan \& } \\
\text { Hrapchak }\end{array}$ \\
2 & Acid Mucopolysaccharides & Alcian Blue & Luna $^{16}$ \\
3 & Basic Proteins & Bromphenol Blue & Chayen $^{25}$ \\
4 & Lipids & Sudan Black B & Chayen $^{25}$ \\
\hline
\end{tabular}

\section{Results and discussion}

\section{Histomorphology}

Stroma was comprised of collagen fibers, fibroblasts, blood vessels, lymph vessels and bundles of smooth muscle fibers. Lacunae were dispersed throughout the stroma both in cortical and medullary region. These lacunae were few at 8 weeks and 16 weeks of age but marked increase in lacunae was noticed at 24 weeks which further increased at 30 weeks.

\section{Cortex and medulla}

The stroma of Punjab white quail ovary consisted of outer cortex (parenchymatous zone) and inner medulla (vascular zone) in all the age groups studied. At 8 weeks of age, there was clear cut demarcation between cortex and medulla (Figure 1). Similarly, Ribeiro ${ }^{18}$ reported that before the gonadal maturation, there were two distinct regions in the ovary: the cortex, a peripheral region where the follicles were found and the medulla region, more central and made of loose connective tissue intensely vascularized and presenting nervous fibers and some smooth muscular fibers in pigeon. At 16 weeks, cortex started to interact with sub cortical medulla (Figure 2). The tunica albuginea which separated cortex and medulla regressed but the two regions could be differentiated. At 24 weeks and 30 weeks of age, the ovary did not show separation of cortex and medulla (Figure 3 \& 4). Similarly, Rao \& Vijayaragvan ${ }^{9}$ in domestic duck reported that distinction between cortex and medulla was not evident. GonzalezMoran ${ }^{19}$ observed that the left ovary showed well-differentiated regions, cortex and medulla at 1 day-old chicken but no distinction between cortex and medulla at 4 week old chicken. However, Deka ${ }^{20}$ in Pati and Chara-Chemballi ducks found that divisions between cortical and medullary layers became obscured. Inner medullary stroma was comprised of well vascularized and innervated connective tissue with lacunae whose covering epithelium changed with advancing age of the birds (Figure $5 \& 6$ ). The medulla was comprised of collagen and reticular fibers (Figure 7) with few elastic fibers (Figure 8-10).

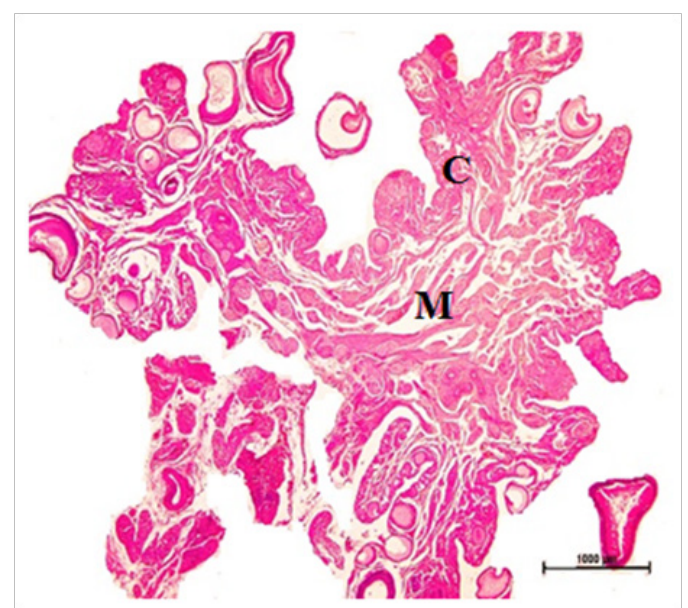

Figure I Fully differentiated cortex (C) and medulla (M) at 8 weeks Hematoxylin and Eosin stain X 20

\section{Surface epithelium}

The entire ovary was covered by single layer of squamous to cuboidal epithelium depending upon the presence of follicles (Figure 11). Similarly, Bharti ${ }^{13}$ found in Indigenous Chicken of Assam that surface epithelium of ovary consisted of single layer of squamous epithelium with few patches of cuboidal epithelium. Bansal ${ }^{14}$ reported 
in Punjab white quail that surface of the entire ovary was covered by single layer of squamous to cuboidal epithelium depending upon presence of follicles. Deka ${ }^{20}$ also reported in Pati and Chara-Chemballi ducks that surface epithelium of ovary consisted of simple squamous epithelium with patches of cuboidal epithelium. Whereas Claver ${ }^{12}$ and Bhavna \& Geeta $^{21}$ reported in spotted tinamous and jungle babbler that ovary was covered by single columnar epithelium containing many follicles in cortical zone. The height of epithelium depended on the presence or absence of follicles. The nuclei of epithelial cells were round or oval with euchromatic basophilic and hyperchromatic material. At certain location, epithelium invaginated into cortical stroma (Figure $12 \& 13$ ).

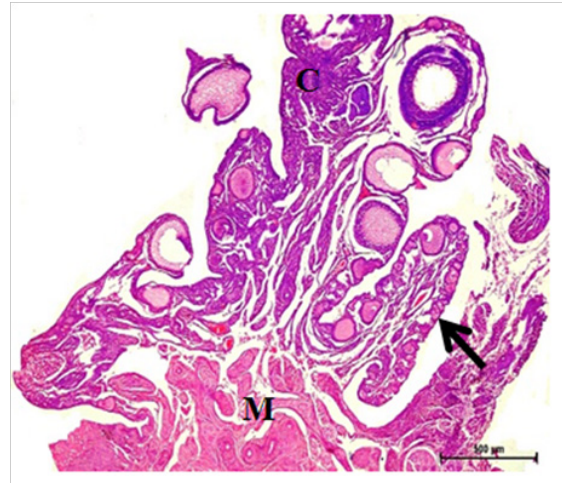

Figure 2 Ovary showing primordial and primary follicles (arrow) in cortex (C), medulla (M) seen in centre at I6 weeks. Hematoxylin and Eosin stain X 40 .

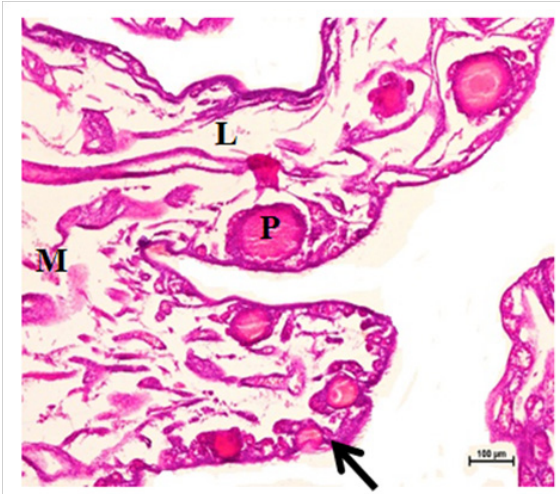

Figure 3 Primordial (arrow) and primary follicles $(P)$ in the cortex. Medulla (M) was composed of connective tissue, lacunar channels $(L)$ and blood vessels at 24 weeks. Hematoxylin and Eosin stain X 100.

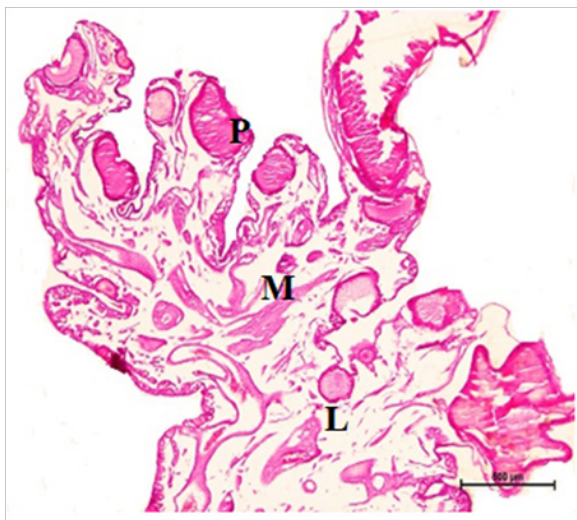

Figure 4 Primary follicles $(P)$, medulla $(M)$, increased lacunar channels $(L)$ at 30 weeks. H\&E stain X 100.

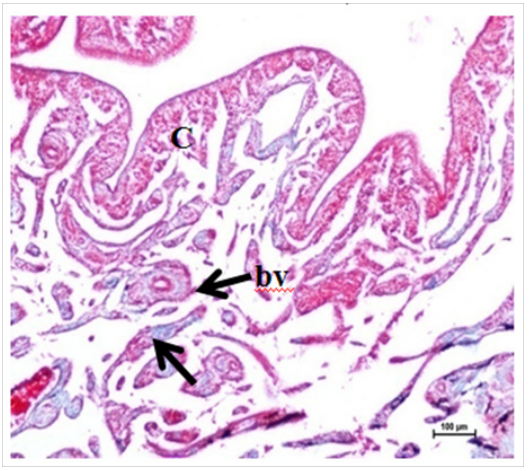

Figure 5 Blood vessels (bv), and collagen fibers (arrow) in medulla at 24 weeks. Masson's trichrome stain X 100.

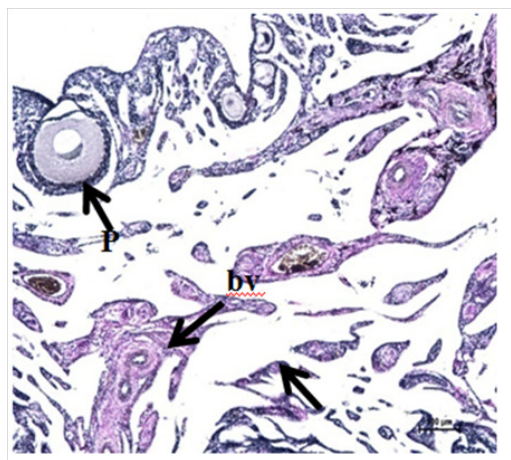

Figure 6 Primary follicles (P) in cortex, blood vessels (bv) and few elastic fibers (arrow) in medulla at 24 weeks. Verhoeff's stain X 100.

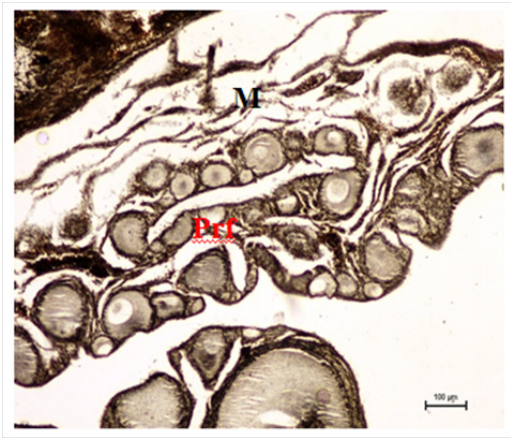

Figure 7 Reticular fibers in primordial follicles (Prf) in cortex and medulla (M) at 8 weeks. Gridley's stain X 100

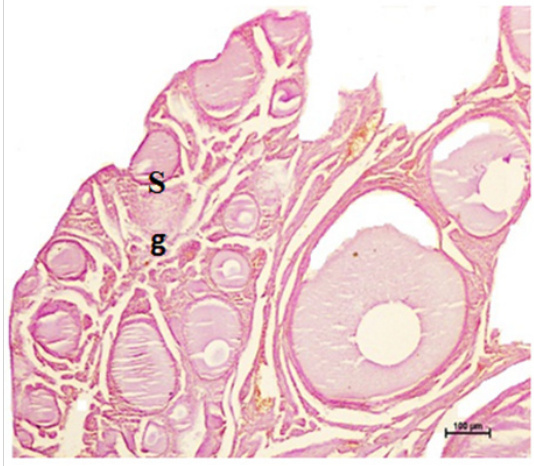

Figure 8 Distribution of neutral mucoploysaccharides in the cortex (C) granulosa and theca layer of follicles at 8weeks. Periodic Acid Schiff's stain $\times 100$. 


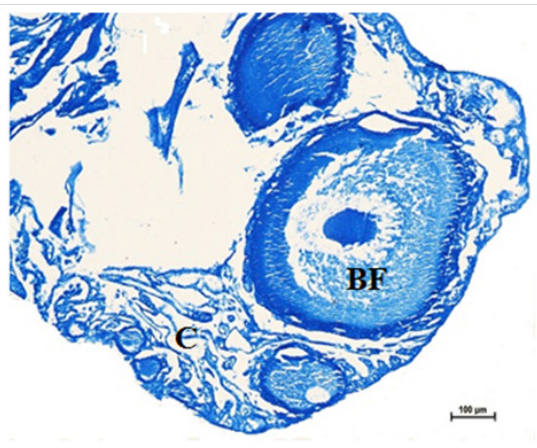

Figure 9 Strong to intense activity of basic proteins in the cortex (C), medulla and follicular wall of the bursting atretic follicles (BF) at 16 weeks. Bromphenol Blue stain $\times 100$

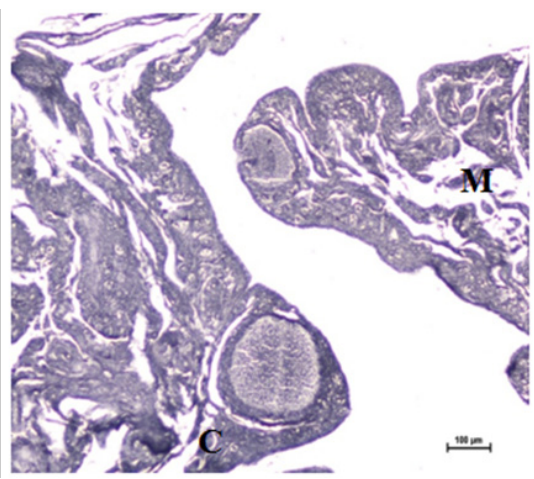

Figure 10 Sudanophillic lipids present in the cortex (C), medulla (M) and follicular wall at 16 weeks. Sudan Black B stain X 100 .

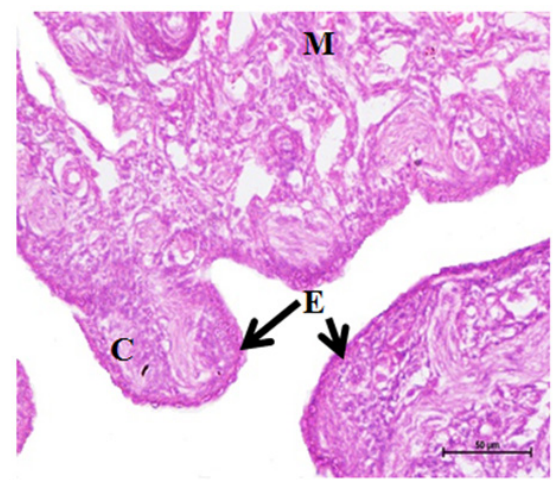

Figure I I Cuboidal epithelium (E) of ovary with irregular crypts, cortex (C), medulla (M) at 16 weeks. Hematoxylin and Eosin stain X 400 .

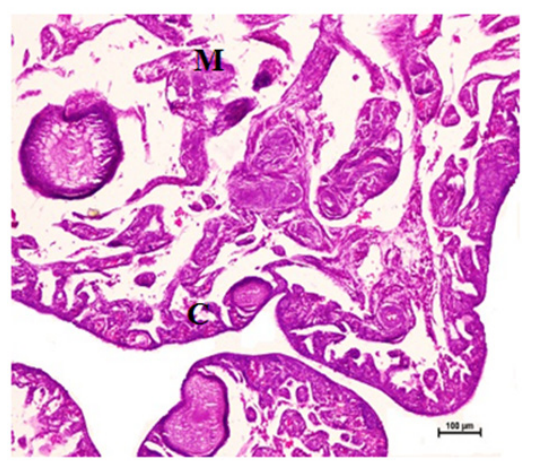

Figure 12 Squamous to cuboidal epithelium, primary follicles in the cortex (C) and medulla (M) at 24 weeks. Hematoxylin and Eosin stain X 100.

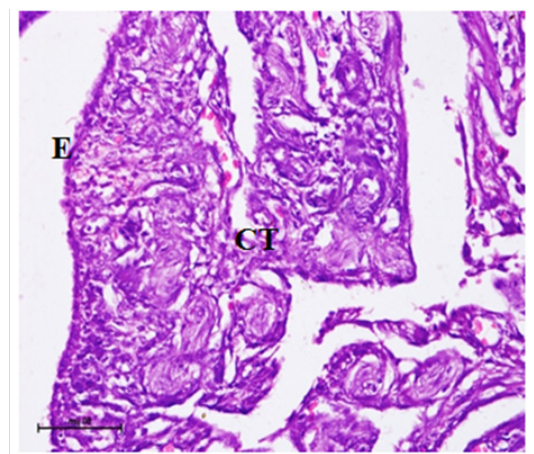

Figure 13 Epithelium (E), connective tissue (CT) and blood vessels at 16 weeks. Hematoxylin and Eosin stain X 400

\section{Tunica albuginea}

The cortex was separated from medulla by a thin layer of connective tissue called tunica albuginea at 8 weeks of age. Similarly, Gonzalez-Moran ${ }^{19}$ observed in chicken that the cortex was separated from medulla by a thin layer of connective tissue, which formed the primary tunica albuginea at 8 day old chicken. The tunica albuginea was composed of abundance of collagen fibers with few reticular and elastic fibers in all the age groups studied (Figure 14). Similar findings have been reported by Bansal ${ }^{14}$ in Punjab white quail. The tunica albuginea was regressed at 16 weeks (Figure 15). At 24 weeks and 30 weeks, tunica albuginea was not found (Figure 16). Similarly, Ribeiro ${ }^{18}$ reported in pigeon that the tunica albuginea got slimmer and the cortical and medulla regions were not distinguished as the gonadal maturation started.

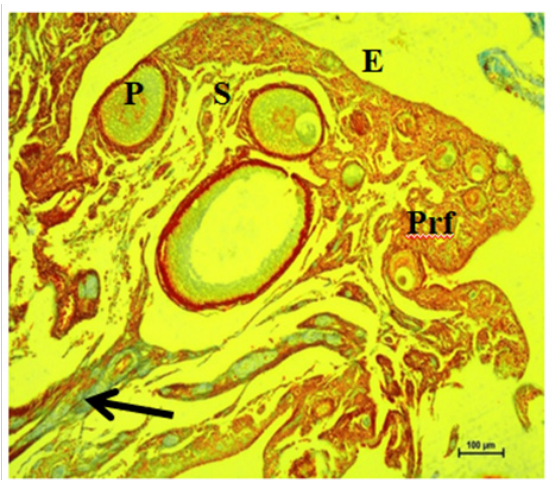

Figure 14 Collagen fibers (arrow) underneath epithelium (E), primordial $(\operatorname{Prf})$, primary $(\mathrm{P})$ and secondary follicles $(\mathrm{S})$ in cortex at 16 weeks. Masson's trichrome stain $X 100$.

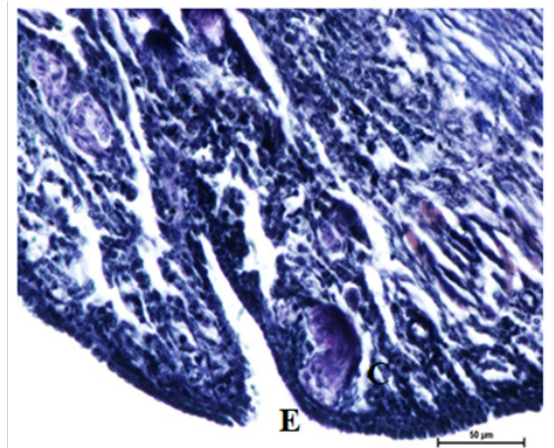

Figure 15 Elastic fibers underneath epithelium $(E)$ of ovary, cortex and medulla, crypts in the epithelium at 16 weeks. Verhoeff's stain X 400 . 


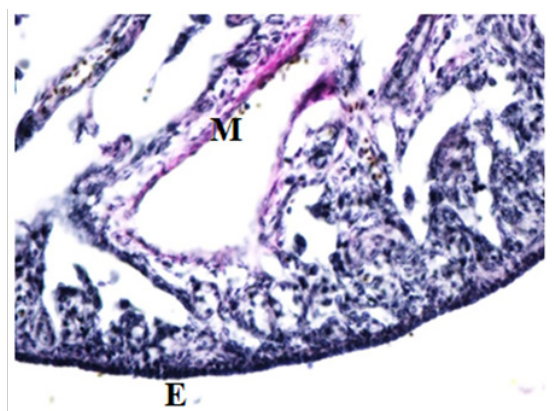

Figure 16 Elastic fibers underneath epithelium (E) of ovary, cortex and medulla (M) at 24 weeks. Verhoeff's stain X 400.

\section{Cortex}

The cortex was occupied by numerous follicles in different stages of development viz. primordial, primary/early previtellogenic, secondary/late previtellogenic, tertiary/vitellogenic, atretic and post ovulatory follicles. In all stages of development, oocytes occupied the entire follicles leaving no antrum as reported earlier by Fitzegerald ${ }^{22}$ in Japanese quail. In the present study, no follicle was found with 2 or 3 oocytes or oocyte with 2 nuclei. Hence the chances of double yoked eggs in Punjab white quail are rare. The present findings are in accordance with Rao \& Vijayaragavan ${ }^{9}$ in domestic duck (Table 4).

\section{Medulla}

The medulla was comprised of loose connective tissue, smooth muscles and large number of blood vessels, fibers, lymph vessels and lacunar channels as reported earlier by Ribeiro ${ }^{18}$ in pigeon. With advancing age, these lacunar channels increased and became wider as reported earlier by Gonzalez Moran ${ }^{19}$ in chicken. The medullary vasculature supplied necessary supply for follicular development. All types of connective tissue fibers viz. abundant collagen fibers along with few reticular and elastic fibers were also present. Similar findings have been reported earlier by Deka ${ }^{20}$ in Pati and Chara- Chemballi ducks. Abundant of collagen fibers with few reticular and elastic fibers were present in the tunica external layer of arteries. Elastic fibers were seen in tunica intima of arteries and veins. Smooth muscle fibers along with nerve fibers were also seen. Veins having erythrocytes in the lumen was also seen in medulla. Similarly, Bhavna \& Geeta ${ }^{21}$ found in jungle babbler that stroma was composed of well vascularized and innervated connective tissue, with spaces (lacunae) whose covering epithelium changed in each period.

Table 4 Micrometrical data on height of surface epithelium, thickness of cortex and medulla of ovary of Punjab white quail at different age

\begin{tabular}{|c|c|c|c|c|c|c|c|c|c|c|c|c|}
\hline \multirow[t]{2}{*}{ Sr. no. } & \multicolumn{4}{|c|}{ Epithelial height ( $\mu \mathrm{m})$} & \multicolumn{4}{|c|}{ Cortex thickness $(\mu \mathrm{m})$} & \multicolumn{4}{|c|}{ Medulla thickness ( $\mu \mathrm{m})$} \\
\hline & 8 wks & 16 wks & 24 wks & 30 wks & 8 wks & I 6wks & $24 w k s$ & $30 w k s$ & $8 w k s$ & $16 w k s$ & $24 w k s$ & 30 wks \\
\hline I & 3.77 & 3.64 & 4.22 & 5.73 & 362.1 & 296.11 & 493.5 & 393.4 & 863.77 & 643.1 & 420.08 & 534.14 \\
\hline 2 & 4.22 & 3.7 & 5.96 & 5.89 & 563.64 & 407.55 & 391.54 & 291.81 & 892.19 & 873.85 & 768.6 & 417.63 \\
\hline 3 & 4.14 & 6.68 & 7.55 & 4.23 & 353.91 & 285.61 & 167.14 & 250.14 & 634.14 & 778.6 & 521.2 & 428.34 \\
\hline 5 & 3.85 & 5.24 & 3.83 & 3.23 & 250.56 & 458.93 & 258.56 & 248.9 & 944.85 & 583.56 & $40 I .45$ & 419.23 \\
\hline 6 & 3.7 & 6.8 & 7.01 & 4.45 & 284.01 & 363.74 & 170.9 & 272.34 & 863.75 & 640.9 & 349.86 & 321.98 \\
\hline Mean士 & $4.391 \pm$ & $5.033 \pm$ & $6.053 \pm$ & $4.608 \pm$ & $385.27 \pm$ & 409.07 & 295.31 & 269.46 & 854.57 & 713.34 & 481.88 & 407.53 \\
\hline S.E. & 0.422 & 0.53 & 0.63 & 0.38 & 45.4 & \pm 49.15 & \pm 47.66 & \pm 28.18 & \pm 42.05 & \pm 40.55 & \pm 56.29 & \pm 29.34 \\
\hline
\end{tabular}

\section{Micrometrical studies}

The mean height of the surface epithelium of ovary was recorded as $4.391 \pm 0.422 \mu \mathrm{m}$ at 8 weeks, $5.033 \pm 0.53 \mu \mathrm{m}$ at 16 weeks, $6.053 \pm 0.63 \mu \mathrm{m}$ at 24 weeks and $4.608 \pm 0.38 \mu \mathrm{m}$ at 30 weeks of age. These findings showed that the mean height of the epithelium increased with the age but was maximum at 24 weeks of age (Table 5). The mean thickness of cortex of the ovary was as $385.27 \pm 45.4 \mu \mathrm{m}$ at 8 weeks, $409.07 \pm 49.15 \mu \mathrm{m}$ at 16 weeks, $295.31 \pm 47.66 \mu \mathrm{m}$ at 24 weeks and $269.46 \pm 28.18 \mu \mathrm{m}$ at 30 weeks whereas thickness of medulla was $854.57 \pm 42.05 \mu \mathrm{m}$ at 8 weeks, $713.34 \pm 40.55 \mu \mathrm{m}$ at 16 weeks, $481.88 \pm 56.29 \mu \mathrm{m}$ at 24 weeks and $407.53 \pm 29.34 \mu \mathrm{m}$ at 30 weeks (Table 5).

\section{Conclusion}

\section{Histochemistry}

The histochemical distribution of neutral and acid mucoploysaccharides, basic proteins and sudanophilic lipids was studied in the ovarian tissues in different age groups of Punjab white quail. The study revealed that distribution of these histochemical moieties did not vary in different age groups but the reaction was variable in different structures of ovary. The histochemical distribution of neutral and acid mucoploysaccharides, basic proteins and sudanophillic lipids in ovarian tissue has been summarized in Table 5. The surface epithelium and tunica albuginea of Punjab white quail ovary showed moderate to strong reaction for neutral mucoploysaccharides (Figure 17) whereas cortical and medullary stroma was moderately positive as reported earlier by Bharti ${ }^{13}$ in indigenous chicken of Assam. They reported intense reaction in the basement membrane of granulosa cells, strong in theca interna, cytoplasm of the oocytes, membrane granulosa and moderate in the ovarian stroma, tunica albuginea and theca externa. The surface epithelium showed strong reaction for acid mucoploysaccharides (Figure 8 \& 18) whereas tunica albuginea and cortical stroma showed moderate reactions, medullary stroma showed weak to moderate reactions. Surface epithelium showed intense reactions for basic proteins (Figure $9 \&$ 19). Tunica albuginea and both cortical and medullary stroma were strongly positive for basic proteins (Figure S). Surface epithelium of ovary showed low lipid content (Figure 20). Tunica albuginea, cortical and medullary stroma showed weak to moderate reactions (Figure 20) as reported earlier by Guraya \& Chalana ${ }^{23}$ in house sparrow ovary. ${ }^{24,25}$ 
Table 5 Histochemical distribution of mucopolysaccharides, basic proteins and lipids in ovary of Punjab white quail

\begin{tabular}{|c|c|c|c|c|c|}
\hline Stain & & Epithelium & TA & Cortex & Medulla \\
\hline PAS & NMPS & $++/+++$ & $++/+++$ & ++ & ++ \\
\hline$A B$ & AMPS & +++ & ++ & ++ & $+1++$ \\
\hline $\begin{array}{l}\text { Bromphenol } \\
\text { Blue }\end{array}$ & Protein & ++++ & +++ & +++ & +++ \\
\hline $\begin{array}{l}\text { Sudan Black } \\
\text { B }\end{array}$ & Lipids & + & $+/++$ & $+/++$ & $+1++$ \\
\hline
\end{tabular}

$0=$ Negative

$+=$ Weak

$++=$ Moderate

$+++=$ Strong

$++++=$ Intense

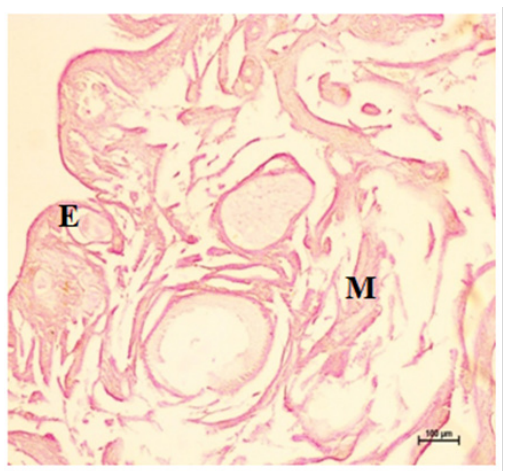

Figure 17 Neutral mucopolysaccharides in the epithelium (E), cortex and medulla at 16 weeks. Periodic Acid Schiff's stain X 100 .

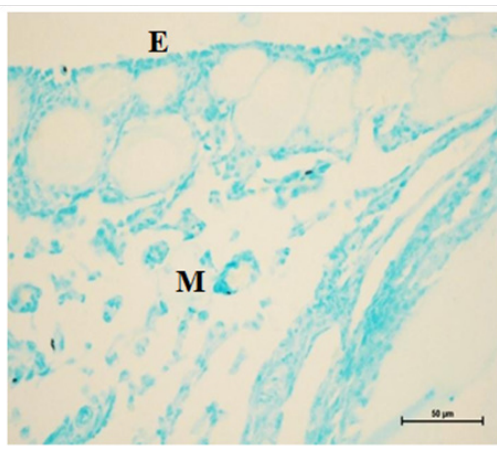

Figure 18 Acid mucopolysaccharides in the epithelium (E), cortex (C) and medulla (M) at 8 weeks. Alcian Blue stain X 400 .

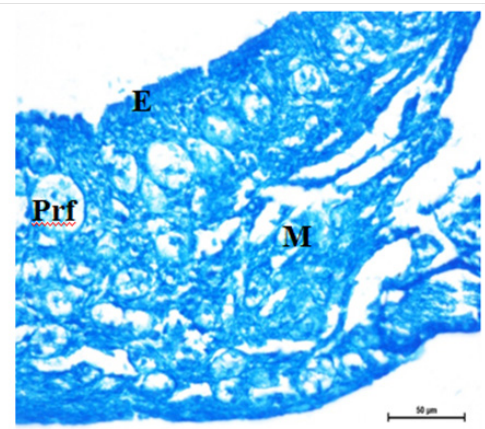

Figure 19 Intense reactions of Alcian blue in the epithelium (E) and moderate in the primordial follicles (Prf) and medulla (M) at 16 weeks. Bromphenol Blue stain $\times 400$.

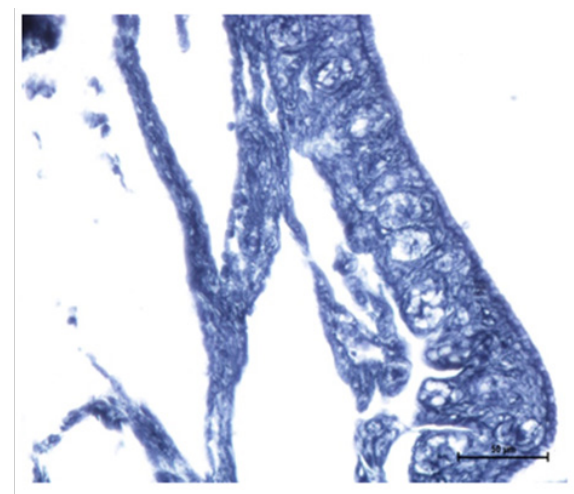

Figure 20 Sudanophillic lipids in the epithelium (E) and primordial follicles (Prf) at 16 weeks. Sudan Black B stain X 400.

\section{Acknowledgements}

None.

\section{Conflict of interest}

The author declares no conflict of interest.

\section{References}

1. Mizutani M. The Japanese quail. Japan: Laboratory Animal Research Station, Nippon Institute for biological science; 2003.

2. Kayang BB, Vignal A, Inoue Murayama M, et al. A first generation micro satellite linkage map of the Japanese quail. Anim Genet. 2004;35(3):195200.

3. Holmes DJ, Thomson SL, Wu J, et al. Reproductive aging in female birds. Exp Gerontol. 2003;38(7):751-756.

4. Vali N. The Japanese quail: A Review. International Journal of Poultry Science. 2008;7(9):925-931.

5. Opinion of the Scientific Panel on Animal Health and Welfare on a report from the Commission related to the welfare of animals during transport. EFSA Journal. 2004;2(5):1-44.

6. Jalees MM, Khan MZ, Saleemi MK, et al. Effects of cottonseed meal on hematological, biochemical and behavioral alterations in male Japanese quail (Coturnix japonica). Pakistan Veterinary Journal. 2011;31(3):211214

7. Saraswati TR, Manalu W, Ekastuti DR, et al. Increased Egg Production of Japanese Quail (Coturnix japonica) by improving liver function through turmeric powder supplementation. International Journal of Poultry Science. 2013;12(10):601-614.

8. Mohammed MB. Histomorphological studies on the development of the ovary in quail. Egypt: Assiut University; 2014.

9. Rao Chandrasekhara TS, Vijayaragavan C. Micro anatomical studies on the ovary of the domestic duck. Indian Journal of Veterinary Anatomy. 1999;11(2):128-132.

10. Rao Chandrasekhara TS, Vijayaragavan C. Histochemical studies on the ovary of domestic duck (Anas boschas domesticus). Indian Journal of Veterinary Anatomy. 1999;11(2):139-142

11. Parida S, Sivakumar M, Ramesh G, et al. Histomorphological and histochemical studies of ovary in Japanese quail (Coturnix coturnix japonica). Indian Journal of Veterinary Anatomy. 2000;22(1):69-75.

12. Claver J, Rosa JM, Lombardo DM, et al. Histological seasonal changes in ovaries of spotted tinamous (Nothura maculosa tinamidae, Temminck, 1815) related to Gonadotrope Population. International Journal of Morphology. 2008;26(2):353-361. 
13. Bharti SK, Gautam AK, Talukdar SR, et al. Histological and histochemical studies on ovaries of adult indigenous chicken of Assam. Indian Journal of Veterinary Anatomy. 2009;21(2):46-48.

14. Bansal N, Uppal V, Gupta A, et al. Histomorphological studies on ovaries of Punjab White Quail. Indian Journal of Poultry Science. 2011;46(2):265-267.

15. Blendea A, Cazimir I, Cornila N, et al. Anatomohistological study regarding the ovary and oviduct in different age groups in the Chicken (Gallus domesticus). Veterinary Medical journal. 2012:8(3).

16. Luna LG. Manual of Histological Staining Methods of the Armed Forces Institute of Pathology. Pathology. 1971;3(3):249.

17. Snedector GW, Cochran WG. Statistical methods. 9th ed. USA: The lowa State University Press; 1994.

18. Ribeiro MG, Teles MEO, Maruch SG. Morphological aspects of the ovary of Columbia livia (gmelin) (Columbidae, Columbiformes). Revista Brasileira Zoologia. 1995;12(1):151-57.

19. Gonzalez Moran G. Histological and stereological changes in growing and regressing chicken ovaries during development. Anat Rec (Hoboken). 2011;294(5):893-904.
20. Deka A, Sarma K, Sarma S, et al. Anatomy of ovary of Pati and CharaChemballi ducks (Anas platyrhinchos domesticus) during laying period. Journal of Agriculture and Veterinary Science. 2015;8(2):33-37.

21. Bhavna B, Geeta P. Histological and histomorphometric study of gametogenesis in breeders and helpers of sub-tropical co-operative breeder jungle babbler, Turdoides striatus. Journal of Cell and Animal Biology. 2010;4(5):81-90.

22. Fitzgerald TC. The Coturnix Quail: Anatomy and Histology. 1st ed. USA: Lowa State University Press; 1969.

23. Guraya SS, Chalana RK. Histochemical observations on the seasonal fluctuations in the follicular atresia and interestitial glands tissue in the house sparrow ovary. Oxford Poultry Science Journal. 1976;55(5):188185 .

24. Sheehan DC, Hrapchak BB. Theory and practice of Histotechnology. 1st ed. The CV Mosby Company; 1973. p. 79-115.

25. Chayen J, Bitensky L, Butcher RG, et al. A guide to practical histochemistry. England: Oliver and Boyol; 1969. p. 83-174. 